THE MAKING OF ITALY AS

AN EXPERIMENT IN CONSTITUTIONAL CHOICE

bỵ:

Filippor Sabetti

McGill Universilty. 
In his reflections on the history of European state-making, Charles Tilly notes that the victory of unitary principles of organization has obscured the fact, that federal principles of organization were alternative design criteria in The Formation of National States in Wéstern Europe.." Centralized commonwealths emerged from the midst of autonomous, uncoordinated and lesser political structures. Tilly further reminds us that "(n) othing could be more detrimental to an understanding of this whole process than the old liberal conception of European history as the gradual creation and extension of political rights . . . Far from promoting (representative) institutions, early state-makers struggled against them." ${ }^{2}$

The unification of Italy in the nineteenth century was also a victory of centralized principles of organization but Italian statemaking or Risorgimento differs from earlier European state-making in at least three respects. First, the prospects of a single political regime for the entire Italian peninsula and islands generated considerable debate about what model of government was best suited to a population that had for more than thirteen hundred years lived under separate and diverse political regimes. The system of government that emerged was the product of a conscious choice among alternative possibilities considered in the formulation of the basic rules that applied to the organization and conduct of Italian governance. Second, federal principles of organization were such a part of the Italian political tradition that the victory of unitary principles of organization in the making of Italy 
failed to obscure or eclipse them completely. Indeed, they gained renewed support after 1860, when the centralized system of government failed to yield the anticipated results. Third, Italian state-making was intended to promote and advance the cause of self-government or what Tilly calls "the old liberal conception of European history." 3 An examination of the Risorgimento serves not only to extend our knowledge of how the issue of centralist versus federalist arrangements was raised and what factors weighted the constitutional outcome in the direction of centralization but also to explore the logic inherent in the different political arguments being advanced to support different proposals for Italian unification. A discussion of the contending arguments will enable us to indicate whether or not the process of constitutional choice articulated an awareness of the consequences that were to be associated with the different ways of organizing Italy. Substantial data now exist about the operational level of the constitutional proposal acted upon in 1860-61. By bringing together the constitutional level of analysis and the operational level of analysis, we can reach conclusions about whether or not, or the extent to which, the Risorgimento yielded consequences consistent with expectations - in essence, to treat the making of Italy as an experiment in constitutional choice.

To treat the unification of Italy as an experiment in constitutional choice accords well with a growing tradition of political inquiry in collective goods and public choices. 4 Italian scholars themselves made important contributions to this tradition in the nineteenth century. ${ }^{5}$ But this is not how how most students of Italian political development have approached the Risorgimento. Historians and social scientists -- 
"Gramscians" and "non-Gramscians" alike -- have given inadequate considerations to the relationship between the principles and forms used in the conduct of the Italian constitutional experiment and the consequences that followed. The forms that the Italian political system took have been generally assumed to have little effect on performance. Having failed to appreciate or understand the limitations and constraints involved in organizing collective human endeavors to undertake developmental opportunities, most analysts have turned to cultural, social or economic variables as the critical factors that explain the gap between expectations and performance and the failure of political institutions "to work as they should." Denys Hay's reflections may be quoted at some length to indicate the paradigmatic problem that plagues the study of Italian political development:

What do we mean by the history of a country? We mean the way that country has acquired selfconsciousness, and the play of interests, political., - social, cultural, within the perimeter established by language, by geography and by relations, acquisitive or concessive, with its neighbors. Put like that it sounds very vague indeed. But I think the statement covers Britain, France and many other sovereign states, where a territory, a language, and a tradition of government are all roughly coterminous with accepted or 'natural' frontiers of some kind. It is, of course, true that we falsify the history of England and France in the eleventh and twelfth centuries if we concentrate 
our attention solely on the ultimate unity. At that time the realities of power were local or at best regional and there was no, obvious linguistic or geographical frontier. But the distortion is less damaging in treating England or France than it would be if applied elsewhere, for by the thirteenth century a rough kind of political centralization was effective. This preface is, I feel, worth making before considering the problem of Italian unity.

Since 1870 Italy has been a country with a single more or less sovereign power (my qualification refers to the pope, not to the Republic of San Marino) and its history has been the story of central government, of regional reactions and regional influences within the framework of central government, and of a foreign policy backed by a single national army. No wonder that in preparation for this historians were active in proclaiming Italian unity and no wonder that since 1870 they have been writing Italian history in the way French or English historians write their history. Yet this approach does not in fact correspond with the realities. No history of Italy can be written on the French or British model which does not seriously distort the true picture. Thus, in a sentence, the basic problem of Italian history is that before the nineteenth century there-is no Italian history, at least not in the same sense as we talk of English or French history. 
The reasons for this are to be sought, in my judgement, partly in the geography, of Italy and partly in the accidents of Italian public life. (It will be -noted that I am illogically accepting the need to explain the diversity of Italy as though unity were the norm: so powerful is the influence of the model histories of sovereign states.) $^{6}$

It takes a student of Renaissance Italy to recognize fully the danger of treating Italian history "as though unity were the norm." Thus a discussion of Risorgimento as an experiment in constitutional choice also represents a basic redirection in comparative analysis - what Sartori calls "from the sociology of politics to political sociology." 7

There is a great deal of controversy among historians as to when the Risorgimento began and when it ended. Some analysts go as far as to date the beginning from the writings on Italy by Dante or Machiavelli and the end to the annexation of Rome in 1870 or Trieste in 1918, but it seems clear that the movement for Italian unification reached its culmination with the formation of the Kingdom of Italy between 1859 and 1861." For our purposes, we can identify two broad phases in the debate about what system of government was best suited to a united Italy. The first phase, encompassing the period from the Napoleonic era to the revolutions of 1848 , is associated with the spread of nationalism and liberalism. The second phase, ranging from the collapse of the 1848 revolts to the proclamation of the kingdom of Italy in 1861, is associated with the hegemony of Piedmont in the unification movement. Whereas the first round of debate was followed by the eclipse of federalism, the second round was followed by the victory of centralization. 
We begin the analysis with an overview of "the problem of Italian unity" as it appeared in the early nineteenth century. We then examine the first phase of the constitutional discussion in terras of the proposals advanced by Mazzini and federalist writers. Next, we turn to the conditions that led to the eclipse of federative alternatives. A discussion of Francesco Ferrara's memorandum to Cavour at the time of the liberation of Sicily from Bourbon rule in 1860 serves to portray .. the second phase of the debate. We conclude the analysis with a discussion of the triumph of centralization.

\section{THE PROBLEM OF ITALIAN UNITY}

Three distinct but interrelated issues went to make "the problem of Italian unity" in the nineteenth century. First, though Italy had always been a territorial unit, it remained divided into several, often small and isolated, states for many centuries. During the Napoleonic period, the various monarchies, principalities and republics vanished, either annexed by France or consolidated in realms ruled by Napoleon's relatives. The Congress of Vienna redivided in 1815 the whole peninsula into eight or nine states, according to "legitimist" and absolutist principles. The republic of Genoa was given to the Piedmontese ruler or king of Sardinia; the republic of Venice was annexed by Austria into her North. Italian province of Lombardy, making up the kingdom of Lombardy-Venetia. Much of central Italy was returned to papal rule. Southern Italy and Sicily became the Kingdom of the Two Sicilies under the Neapolitan Bourbons. The system of centralized government and administration introduced by the French became a useful instrument to solidify or extend absolutist rule. Only in the Austrian 
Kingdom of North Italy there continued to be a large measure of local and even regional self-government after 1815. The table of Italian states as they appeared in 1846 shows how the people of Italy were ruled by different sovereigns,

(table about here)

Second, the settlement of Italy reached at the Congress of Vienna was part of a larger settlement for the maintenance of European peace. The "trustee" of that European peace in Italy was Austria. It not only possessed Lombardy-Venetia but also controlled the duchies of Tuscany, Parma and Modena and had its military forces positioned to suppress insurrections as far south as Sicily. Moreover, the central Italian states or legations held by the papacy were deemed essential prerequisites and signs of the catholic patrimony of the church. The problem of Italian unity was a European and international problem as well.

Third, the political divisions that had existed on the Italian peninsula for more than 1,300 years had given rise to, and supported, a strong attachment to community and regional affairs as well as an extraordinarily diverse set of social institutions, cultures and languages. As late as 1850 Latin and not Italian was the lingua franca of Italy; by the early 1860 's, it has been estimated that only about. 160,000 out 9

of 20 million people could speak the official language. The two most important dimensions of the political consciousness of inhabitants of the Italian peninsula were, to use Gramsci's pejorative or disparaging characterization, "municipal particularism and Catholic cosmopolitanism." As a result,

(T) he case of Italy was entirely different from that of Poland or Greece or any other of the 
(Table for pg. 7)

STATE

Piedmont-Sardinia

(Kingdom)

Lombardy-Venetia

(Kingdom)

Tuscany

(Grand-duchy)

Modena

(Duchy)

Parma

(Duchy)

Lucca

(Duchy

San Marino

The Papal States

The Two Sicilies
RULER

POPULAT TON

Charles Albert of Savoy

Emperox Ferdinand of Austria

Leopold II (first

cousin of Austrian emperor)

Francesco IV

(Austrian Este)

Empress Marie Louise

(Napoleon's widow, Austrian)

Charles-Louis of

Bourbon

$4,916,084$

$5,000,000$

$1,534,740$

575,410

497,343

165,198

Republic

$$
7,800
$$

Pope Pius IX

$2,898,115$

Ferdinand II (Spanish Bourbon) 


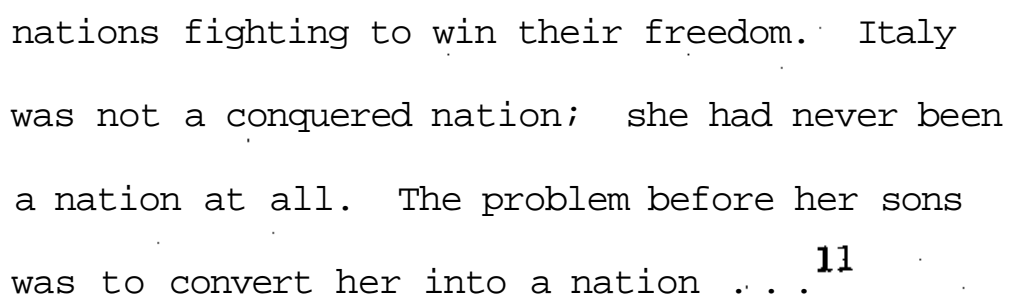

A forced creation of unity was insufficient to effect the Risorgimento. Neither the nature of the country nor the political consciousness of its inhabitants could be ignored or denied without danger. The resolution of the problem of Italian unity that respected and advanced the cause of self-government was, in fine, an exceedingly difficult undertaking .

THE FIRST PHASE OF THE CONSTITUTIONAL DEBATE:

UNITARISM VS FEDERALISM

The Napoleonic hegemony over the Italian peninsula between 1796 and 1814 helped to foster the idea that some kind of Italian nation existed or ought to exist. But even in northern Italy, where French influence was most pronounced, Italian nationalism had very few supporters and advocates. The Congress of Vienna, by treating the Italian peninșula as a convenient spoil of the war, generated dissatisfaction about absolutist government. . But rebellions against governmental oppres-sion or the spread of liberalism did not necessarily coincide with, or strengthen, Italian nationalism. For example, as late as 1847 liberals in Naples and Sicily had no or negligible part in the development of a pan-Italian nationalism. Sicilian liberals wished to end absolutist rule and to free Sicily from "the yoke of Naples." Neapolitan liberals 
wished to end absolutist rule without, however, breaking up the territorial integrity of the newly established Kingdom of the Two Sicilies. ${ }^{12}$ For these reasons, the first phase of the constitutional debate took place essentially among Septentrionals who, with the exception of Mazzini, may be described more as analysts rather than as participants of the Risorgimento.

\section{A Unitary Republic}

In 1796, following Napoleon's occupation of Lombardy, the French administration at Milan offered a prize for an essay on what type of government would best suit Italy. The prize was won by an advocate of 13

a unitary republic, Melchiorre Gioia. Federal principles of organization were ruled out in part because a system of government built on such design criteria would be "inevitably slow when it comes to planning, slower still when it comes to carrying plans out, and only too ready for disagreement." ${ }^{14}$ A unitary republic was expected both to overcome regional and municipal loyalties and to act with speed and dispatch.

Mazzini proposed a similar structure of government. But unlike Gioia's, Mazzini's proposal was not just a literary exercise. In 1831, he founded a secret patriotic society, "the Young Italy," to prepare the grounds for "the Italian revolution" that would free Italians from the tyranny of princes. In 1853, Mazzini organized a "party of action" to continue the earlier work. He, in fact, devoted his life (1805-72) to the cause of Italian independence and unification. But throughout his life.Mazzini gave scant consideration to the shape or form of his unitary republic. For him, the making of Italy took precedence over a concern for individual liberty and self-government. It 
is no accident that by 1859 many of Mazzini's supporters were siding with unification efforts taking place under the Savoy monarchy. But, "the immediate result of Mazzini's teaching was to fan to a blaze the embers of Italian nationality." 16

\section{A Gonfederation of Princes}

Vincenzo Gioberti's book On the Moral and Civil Primacy of the Italians, published in 1843 at Brussels where the author (1801-52) lived in exile, challenged the idea of a unitary republic. Gioberti took particular issue with Mazzini's plans for a forced creation of Italy:

The aim of the strict unitarists may be good in theory, but they would suit us only if effective in practice .. . It is madness to think that Italy, which has been divided for centuries, can be peacefully united in a single unitary state; and to want this brought about by force is a crime . . . A united state would be almost impossible to create even at enormous cost, let alone keep in being. I would go even further and say that a centralized Italy is against the sheer facts of history and the character of our people; at least all the available facts go to show this .17

He proposed, instead, a league of existing states under "the moderating 18

authority of the pontiff." This neo-Guelph confederation was expected, among others, 1) to minimize and eventually remove foreign interferences in Italian affairs; 2) to make Italy a European power; and 3) to 
"eliminate or at least reduce the differences in weights, measures, currencies, customs duties, speech and systems of commercial and civil administration which so wretchedly and meanly divide the various provinces ..." 19

Unlike Mazzini's writings, Gioberti's work became very popular throughout the Italian peninsula. As Bolton King observed, "(t)he clergy were won by its Catholic tone; the nationalist statesmen by its praise of the Savoy princes." 20 It was, however, too much to hope that Italian nationalists and princes would be prepared to accept a confederation under the papacy. As a result, Gioberti's plan remained just that, and not before long Gioberti himself abandoned it.

Yet, Gioberti's work played an important part in the ongoing constitutional debate for at least two reasons. First, its popularity and appeal to the "moral and civil primacy of the Italians" spread the idea, and gained new adherents to the cause, of Risorgimento. Second, by challenging Mazzini's unitary republïc, it oriented the debate on what model of government was best suited to Italy toward federalism.

\section{A Customs Union}

Cesare Balbo's On the Hopes of Italy, ${ }^{21}$ published at Paris a few months after the appearance of On the Moral and Civil Primacy of the Italians, shared Gioberti's views about centralized Italy but rejected Gioberti's proposal of a neo-Geulph confederation. The pope was likely to be the enemy of a larger Italian political union. Balbo's work was a kind of "manifesto" for a circle of Piedmontese intellectuals and politicians who held the view that independence must be sought before all else -- even before unity and constitutional. liberty -- and that its 
attainment would come only when Austria voluntarily gave up her possessions and spheres of influence in Italy. 22 In preparation for that event, Balbo (1785-1853), who was prime minister of Piedmont in 1848, pressed for free trade and a customs union among the Italian states as prerequisites for the peoples of the peninsula to feel a common identity.

\section{A Federation of Peoples}

The case for a federal union was best made and advanced by Carlo Cattaneo (1801-69), a Lombard publicist and one of the foremost Italian federalist thinkers. ${ }^{23}$ Disagreeing sharply with Mazzini and Balbo, he suggested that Italian unification could not be obtained at any price least of all at the price of liberty and self-government. Recalling the French political experience, Cattaneo noted that a forced creation of Italy through a unitary or centralized system of government would hinder rather than facilitate self-rule and human development." He rejectéd Gioberti's confederation of princes and called for a federation of peoples, This federation or United States of Italy was.. expected to take the form of a polycentric system of government with overlapping jurisdictions - what has been called "a compound republic." 24 such a system of government was, for Cattaneo, the theory of democracy in a ction for it . reconciled, preserved and fostered order with liberty, union. with diversity and 25

self-rule with shared rule. Like modern public choice analysts, Lombard publicists like Cattaneo had considerable appreciation for the genius of the eighteenth-century philosophers who recognized that the self-interest of individuals can be made to serve and advance the commonweal under the appropriate institutional arrangements. 
Cattaneo as well as other federalist patriots believed that : a compound republic could be established in Italy on the basis of reflection and choice rather than through force or by accident. They drew inspiration and support for their national political program not only from the American, Jewish and Swiss political tradition but also from developments taking place in Lombardy-Venetia. There under Austrian rule was taking plàce a veritable agricultural, industrial, commercial and educational revival that had all the characteristics of a Risorgimento, No army of occupation could defeat such "conspiracy in broad daylight".
A S
$\mathrm{K} e \mathrm{n} t$
$\dot{R} \circ \mathrm{b}$ e r t $\mathrm{s}$
Gre e $\mathrm{n}$ f $\mathrm{i}$ e $l \mathrm{~d}$
ob-

served in his now classic work Economics and Liberalism in the Risorgi-

mento: A Study of Nationalism in Lombardy 1814-1848:

- . it is clear that in the inner circle of publi-

cists who ventilated the public interests of Italy

between 1815. and 1848 there was a common idea that

even when cooperating with Austria they were working

towards ends that were beyond the reach of Austrian

policy, and also a common conviction that they were

in conspiracy with the course of events, with the

march of 'the century;' in other words, that they

had found a method of action which compelled even the

national adversary to cooperate with them, in so far

as that power was alert to its material interests. This

was their 'conspiracy in open daylight.' They were

right in their strategy: witness the confused and

helpless opposition of Austria, whose rulers suspected 
but never fully comprehended their, power. Metternich, with his germ theory of revolution, his persistent obsession that it grew solely out of a Jacobinical conspiracy which could be isolated and destroyed if the governments would only act in concert, proved incapable of meeting them on their own ground.

It may also be said that . . liberal journalists (like Cattaneo) saw at least a partial fulfillment of their hopes. By 1848, largely through their efforts, an Italian public opinion had been formed that could never again' be governed successfully by the principles. and methods of the ancien regime, less because the material interests of the Italian community had been revolutionized than because the public had been indoctrinated with a new conception of those interests. ${ }^{26}$

THE ECLIPSE OF FEDERALISM

The revolts of 1848 began with the Palermo uprising against Bourbon rule in January 1848, forcing king Ferdinand to give up absolutist rule and to grant representative institutions to Sicily as well as Naples. The Sicilian and Neapolitan revolts, together with the February uprising in Paris, convinced king Leopold of Tuscany and pope Pius IX to grant constitutions. King Charles Albert of Piedmont also yielded to liberal pressures. On March 4, 1848, he granted representative institutions in the form of the Statuto which was to remain the basic law of Italy until 1946. 
The pressures for representative Institutions reached Vienna and led to the fall of Metternich. News of this revolt triggered revolts in the Austrian provinces of Lombardy and Venetia. Risorgimento "men of thought" like Cattaneo became "men of action" in the famous "five glorious days of Milan." Venetian revolutionaries and followers of Mazzini proclaimed the restoration of the ancient republic of Venice. The Piedmontese ruler came to the support of all these revolutionaries by ranging his army against Austrian forces still in Italy. Soon afterward, the regular armies of Naples, of the papal states and of Tuscany joined forces, with those of Charles Albert, Cattaneo federalists and Mazzini republicans in fighting against Austria. Such unity of action among princes and patriots went.far beyond any constitutional alternative heretofore contemplated in discussions about Italian independence. But the high probability of success suggested by this "federation of princes and peoples" laid bare insurmountable contradictions in the movement for Italian independence that could not be reconciled in revolutionary times.

Charles Albert's insistence on political fusion of LombardyVenetia with his kingdom both disillusioned Lombard and Venetian liberals and led other Italian rulers to desert the fight against Austrian domination. Soon afterward, the Neapolitan and Tuscan monarchs withdrew their liberal constitution and, with Austrian help, became once again absolutist rulers. It became eminently clear that Pius IX could be neither a liberal pope nor an Italian-nationalist ruler. His dominions stood for universalism rather than nationalism. Sicilian revolutionaries, who had joined the movement for a United States of Italy as a way of insuring Sicilian independence from Naples, found that 
self-government was extraordinarily difficult to maintain in war time. 27 By 1849, all the uprisings collapsed and became, in retrospect, "the first war of Italian independence."

The failure of the 1848-1849 revolts had several consequences for the making of Italy. First, it lent credence to Mazzini's view that the struggle for Italian unification and independence must take precedence over the issue of what system of government best suited Italy: The constitutional questions raised during the revolts - monarchy versus republic, centralization versus federalism -- had impeded rather than facilitated the success of the uprisings. Second, it "ended neo-Guelph programs for Italian federation under the (p) apacy and greatly weakened any claims for federalism." ${ }^{28}$ Third, it "established that all of Italy's crowned heads, except possibly Piedmont's new king, Victor Emmanuel II, were anti-nationalist." 29 After 1849, the Kingdom of Sardinia stood out in sharp relief as the only parliamentary monarchy in Italy. As a result, Piedmont "was left the one hope of Italian liberals, and for the next ten years the history of Piedmont is the history of Italy." ${ }^{30}$

THE SECOND PHASE OF THE CONSTITUTIONAL DEBATE: CENTRALIZATION VS DECENTRALIZATION

The second phase of the constitutional debate occurred in the yeárs immediately before and after the proclamation of a united Italy in 1861. At least four distinct but interrelated circumstances of the period are important for our analysis. First, in 1857, a "National Society" was formed in Turin to support and spread the idea that Italian liberation depended on the actions of the Piedmontese government headed 31

by Cavour. As the work of Raymond Grew suggests, this National Society attracted the support of Tuscan liberals as well as the support of 
Garibaldi and other former companions of Mazzini. Second, recognition of the hegemonic position of Piedmont in the Risorgimento carried with it an implicit acceptance of its system of centralized government and administration as the model of government for all of Italy and of its army as the principal instrument of national liberation. 32 The movement for Italian unification was viewed by Victor Emmanuel and Cavour also as an opportunity to realize dynastic and Piedmontese aggrandizement. Third, whereas before 1848, Austrian presence in Italy had guaranteed European peace, after 1849 it became a threat to that very peace. ${ }^{33}$ The. French emperor, Louis Napoleon, sought to replace Austrian with French influence in Italy and perhaps even to make Italy a satellite of France. 34 Fourth, the suppression of the 1848 revolts in places like Sicily generated a more diffused spirit of liberalism which, in turn, encouraged more popular unrest against governmental oppression.

This interweave of national and international circumstances gave rise to several developments. In 1859, there was the FrancoPiedmontese war against Austria which, in part, secured Lombardy for Piedmont. In the same year, uprisings in central Italy drove the various dukes out of power and prepared the grounds for the annexation of central Italy by Piedmont. ${ }^{35}$ In April 1860 a popular revolt against Bourbon rule erupted in Sicily. The May 1860 landing of Garibaldi's "Thousand Men". at Marsala consolidated the revolt and opened the way both for the collapse of the Kingdom of the Two Sicilies and for the unification of the South with the North. As this chain of events weighted the making. of Italy in favor of a unitary and monarchical state, the constitutional debate became centered on a choice between centralized and decentralized ${ }^{36}$ models of government. 
Perhaps nowhere else as in Sicily the choice of rules that apply to the organization and conduct of government was most felt and debated. Sicily had been until 1816, when it was annexed to. Naples, a more or less independent realm, with the longest tradition of representative institutions in Italy. Sicilians had joined the cause of Italian unification only in 1848, when the possibility of creating a United States of Italy offered prospects for regaining independence from Naples, for securing defense against the recurrent problem. of war and for being part of a larger political community which respected the need for local and regional self-governing capabilities. Sicilians had become Italian nationalists because of federalism. Now, while.Piedmontese saw themselves as coming to deliver Sicily from bondage, Sicilians came to view the reiteration of unitary principles of organization as a change from the yoke of Naples to the yoke of Piedmont or Italy. 37

One of the Sicilians to take part in the constitutional debate was Francesco Perrara (1810-1900), the most prominent Italian political economist of his time. Ju In July 1860, as Garibaldi began to rule Sicily in the name of Italy and Victor. Emmanuel, Ferrara wrote a memorandum to Cavour, whom he knew well from his years in exile in Piedmont following the collapse of the 1848 Sicilian uprising. The memorandum entitled "Brief Notes on Sicily," outlined șeveral possible ways of uniting Sicily to the nascent Italian realm. ${ }^{39}$ A presentation of the principal points raised by Ferrara serves to illustrate the range of constitutional choices available at the time and to elucidate, more generally, the problem that confronts people in the design of governmental arrangements -namely, to know how different sets of principles articulated in correlative forms can be expected to yield different results. 


\section{Sicily in the Constitution of Italy}

Ferrara began his reflection by noting that his analysis was grounded upon one fact and one principle:

(T) he fact is that the Sicilian revolution springs solely from the irresistible desire to break free from Naples. The cries raised, the principles invoked, all simple phrases to which recourse is had spring purely from reasons of political necessity, and which could be altered from one hour to another with any change in circumstances: the words 'nationality' and 'unity' therefore represent means and not ends . . . 40

The principle. . . is this: Piedmont has an interest in supporting the present vogue of annexation (among Sicilians) but has an even greater interest in bringing it about in such a way that annexation is transformed from a condition of necessity to a condition of mutual consent (volontà). It is important that we should prevent Sicily becoming the running sore of the kingdom of Italy as she has been of the Bourbon state. . .

On the premise that Sicilians wanted annexation as a means rather than as an end and that Piedmont had an interest in transforming it into an. end, Ferrara thought through four alternative "systems" or ways of uniting Sicily to Italy and recommended the choice of one "system" over the others in terms of relative advantages.

"The Swedish-Norwegian System." This alternative involved a 
union of Sicily with the nascent Italian kingdom much like the King of Sweden was also the King of Norway. There would be no union of the institutions of each kingdom. Though this solution was one that "every Sicilian desire(d), but no one ask(ed), ${ }^{42}$ Ferrara suggested that it should be rejected for it would be less profitable to the interests of Sicily and even more damaging to the interests of Italy. Sicily would never have the certainty of being defended against invaders, The arrangement would also weaken unity of action. Such a system of government would insure neither safety nor happiness. Indeed, the development of each country would proceed along different paths. As a result, there could well come a time when their interests would become so disparate that, though under the same monarch, the two countries could find themselves in opposite camps. Break-up of the system would follow. Hence, Ferrara reasoned, this type of government was not appropriate for Sicily and Italy.

"Complete fusion." Complete fusion on the French model of government and administration meant that Sicily would become just another province of Italy, as had happened to Lombardy and Tuscany. Ferrara informed Cavour that, though this solution was one that Sicilians asked when they said "annexation," no one in fact desired it. His assessment may be quoted at some length:

The principle of fusion with the North now being preached is the very negation of liberty, concealed under the invocation of liberty Itself: it is even a form of political socialism. It would be a fatal error if Italians showed that they could not emerge from the excesses of municipalism without throwing 
themselves into the other extreme where unity is confused with absorption ... 43

Ferrara anticipated that

Complete fusion would be quite impossible to carry out in Sicily, simply because of the profound revolution it would involve for the customs and habits of Sicilians. Secondary laws . . will have to be changed without necessity but for reasons of assimilation . . A system of local government will be introduced quite different from that which has been the ideal and passion of Sicilians. . . The public debt would be increased fourfold at one stroke in a country which would not have the resources for it. The system of taxation would have to be completely changed .... Apart from the difficulty of introducing military conscription, many unfortunate changes would be made in the system of administration, in money, weights, even in language: and the supreme court of appeal would have to be abolished. Further difficulties would arise through the sheer distance away of the new capital, and through the presence in Sicily of nonSicilian officials ... All these innovations would be found impossible to apply in practice, however simple they may seem in the abstract. . . 44 
He continued:

Sicily has never had in its history known such a fusion as this except with Naples between 1838 and 1848; and on that occasion it was such a fusion that forced the island into revolution... . The politics of a distant, vaster and more complex government and, above all, if it is Parliament, however inspired by the most benevolent of intentions, will never be so prompt, far-sighted and active as to meet the needs of Sicily which will disappear in the great mass of Italian national affairs. There seems no doubt that fusion would make Sicily the Ireland of Italy and hence, instead of making our nationality more compact and secure, would be a real and perennial source of weakness from which an enemy could profit.

For these reasons, Ferrara rejected centralized government and administration. He then turned to a discussion of two other alternative designs of government.

"The Scottish System." This model of government meant that Sicily would, with the exception of the authority of the national parliament, keep its secondary laws and Institutions. Ferrara was, however, skeptical that such an arrangement would work in the same way that it worked in Great Britain, The problem in Great Britain was to bring together peoples whose traditions of individual liberty and local autonomy were so historically established that the London parliament could not equate the felicity of subjects with the destruction of voluntary 
efforts and with the erection of a Leviathan. But, Ferrara reasoned, "in our epoch eminently Napoleonic" ${ }^{46}$ it would be futile to entertain similar expectations from a general parliament of Italy. The destruction of Tuscan autonomy that was taking place supported Ferrara's apprehension about the advisability of transplanting the Scottish system to Sicily. He then turned to a consideration of a fourth model of government that appeared to have none of the shortcomings of the others and that, under the circumstances, best reconciled a desire for Sicilian self-government with a desire for Italian national unity.

"The American System." Applied to a monarchical and unitary state like the Italian kingdom, "the American system" stood for central government decentralization or regional and local autonomy. Ferrara offered a sketchy and inadequate portrayal of this type of central government decentralization. He did, however, indicate the principle on which such institutional experiment could be carried out and some of the reasons that made it a desirable experiment.

The principle was the following: "nothing that is truly necessary for the expression of the Italian nationality should be taken away from the general parliament of Italy: nothing without proper cause should be taken away from the expression of Sicilian self-government." ${ }^{47}$ The application of this principle would, according to Ferrara, neither lower the dignity of the monarchy nor make Italy less compact. "It (was)," he said, "a common error to attribute more cohesion to a state whose government takes on tasks that subaltern bodies or individuals can do better." 48 Emphasizing the covenantal basis of constitutional choice, Ferrara warned that "(w)hoever knows (Sicily) well must be convinced that annexation, on conditions which Sicilians might later regret, would 
soon generate sentiments not wholly Italian, which interested parties would not omit to nourish." 49 In sum, "the American system" had the additional advantage of securing a calculus of consent for the constitution of Italy.

In the last sentences of his memorandum to Cavour, Ferrara looked to the future and anticipated another advantage that would accrue from the American system. He observed:

Who can ever tell that the solution currently being advanced for Sicily might not, some day, be extended to other parts of the peninsula? Certainly, ideas of rigid centralization are not native to Italy ... and no other part of Italy is as distinctive as Sicily. The Italian government could profitably carry out an experiment there which could do no harm. It might be a source of precious information for the future, if it ever came the day either to proceed to "other annexations . . or to decentralize government in some of the regions already annexed. 50

The Piedmontese prime minister neither acknowledged nor answered directly Ferrara's memorandum. Writing to a third party, Cavour dismissed Ferrara's analysis with the following observation:

If the Italian idea has no influence in Sicily, if the idea of building a strong and great nation is not appreciated there, Sicilians would do well to accept the 
concessions offered by the king of Naples, and not unite themselves to people who would have no sympathy or esteem for them. 51

But, as the research on Cavour and Garibaldi 1860 by Denis Mack Smith ${ }^{52}$ makes clear, by that time Sicilians could neither turn back to the Bourbon' monarchy nor not unite themselves to the Savoy monarchy. Unconditional annexation followed, to make of Sicily a province of one and indivisible Italy under Victor Emmanuel II as king.

THE TRIUMPH OF CENTRALIZATION?

The Law on Administrative Unification of March 23, 1865 signalled the defeat of last minute efforts at central government decentralization and assured the triumph of centralized government and administration. The new nation state was organized as a single center of authority with an exclusive monopoly of the ultimate use of physical force in the organization of society. " The monopoly over the supply of public goods and services was accompanied by a single overarching system of public administration with local elected officials and professionally trained personnel hierarchicâlly ordered and subject to'direction by heads of departments at the center of government. 53 Unlike the French prefect, however, the Italian provincial prefect was not given authority over all other field offices of the national system of administration. As Robert C. Fried observes, "the liberal ideology of the ruling groups was not favorable to the accumulation of power in a single provincial official of the vice-regal or 
proconsular type." 54 Moreover, it was felt that the provincial prefect, already burdened with the task of being all at once the political representative, of the national government, the chief of police and the. supervisor of local government, would be unable to provide expert direction and full-time coordination to all the provincial field officers of the central bureaucracy. Hence each field service had its own directoror "prefect." The Italian administrative system was designed to minimize goal displacement and risk avoidance as well as to maximize the uniform application of national legislation:

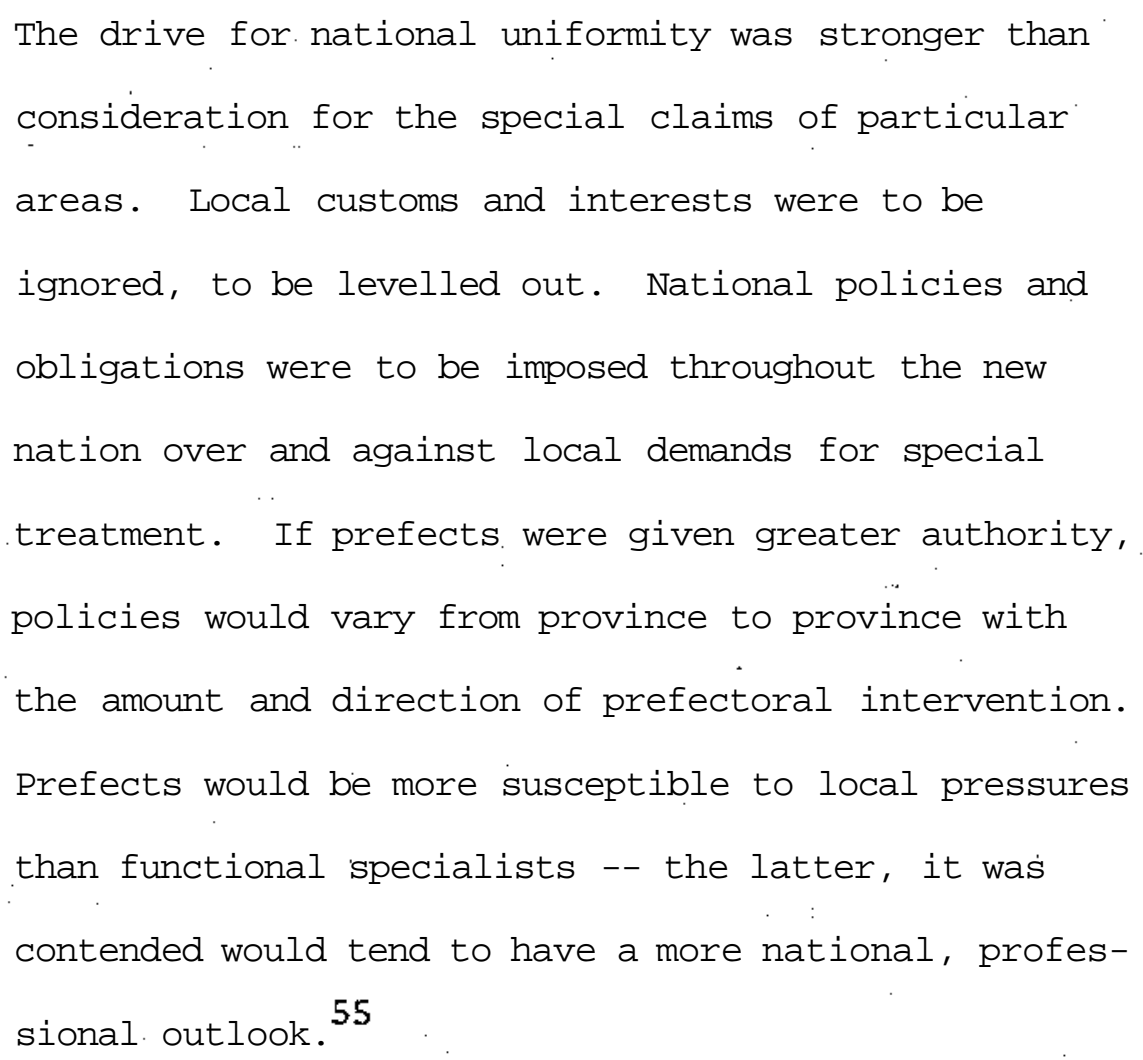

In sum, the fathers of Italian unification anticipated forced creation of unity through administrative measures under a common parliament, backed by a national army, to 1) forge the diverse communities of peoples into one strong and great, self-governing nation, 2\} insure a uniform 
provision of public services and 3) remove once and for all the specter of foreign intervention in Italian affairs.

Did such a system of government work to attain the results that its creators expected to realize? 'Did unitary principles" of organization triumph in practice as they did in theory?

The history of united Italy is essentially the history of a system of government that hàs not yielded consequences consistent with expectations. 56 From the perspective of central government officials; citizen dissatisfaction with this state of affairs reflected a lack of patriotism; attempts by local officials to be responsive to citizen preferences or "local interests were perverse manifestations of responsiveness; local efforts to. secure home rule or to assert an inherent right of self-government were expressions of parochial values; and mutual aid societies were mafia or criminal associations. Sicily became, as Ferrara had predicted, "the Ireland of Italy."

The system of government not only did not work to attain the results that its creators had expected to realize but also gave rise to a situation whereby it became increasingly difficult for public officials to discern the causes that generated "social pathologies." Efforts to improve performance or rejuvinate the nation took the form of "historical coalitions" of successive political classes at the helm of government - without, however, basic changes in the instrumentalities of government. Thus transformismo gave way to Fascism, and Fascism to democratic centrism - the lack of fit between the theory and practice of the unitary system of government remained. Modern calls for a Communist-led "historical compromise" to improve performance and to rejuvinate Italy arebbut a novel reiteration of previous reform efforts. 57 
At the same time, political writers, by accepting the need to explain Italian political development "as though unity were the norm," or through the model history of France, have given little attention to the limitations and constraințs inherent in that norm or model history. Witness what Antonio Gramsci said about artificers of Italian unification lịke Cavour:

They said that they were aiming at the creation of a modern State in Italy, and they in fact produced a bastard. They aimed at stimulating the formation of an extensive and energetic ruling class, and they did not succeed; at integrating the people into the framework of the new State, and they did not succeed ... . They made the people-nation into an instrument, into an object, they degraded it. And therein lies the greatest and most contemptible demagogy ... 58

Gramsci's denigration of the work of the fathers of Risorgimento is correct only if one accepts the view that they were "supermen" -- mortal gods who failed to do what was in their power. This is not political analysis. It is political mythology. And it is no accident that Gramsci's Modern Prince has all the characteristics of Hobbes' Leviathan. 59 Thus, the failure of centralization "to work as it should" has also been accompanied by a failure to develop an adequate understanding of the relationship between the principles and forms used in the design of the Italian experiment and the consequences that followed. 
CONCLUSION

The issue of what principles of organization would best suit a liberated and united Italy reflected not only the varying conditions in which Risorgiraento men of thought operated but also the changing fortunes of the disparate elements that pressed for unification over the course of about 50 years. Federalist and autonomist principles of organization led Cattaneo and Ferrara to believe that local and regional loyalties could be made to work for the commonweal under appropriate institutional arrangements. Unitary principles of organization led Cavour and others to ignore or try to suppress them. In the end, unitary principles of organization prevailed.

The kingdom of Italy, was hailed, not unjustifiably, as one of the most notable achievements of the nineteenth century. But no sooner had Italy become a nation-state that the consequences of. its system of government permanently flawed the success of Risorgimento. By shifting the focus of historical investigation away from Italy as a predestined unitary state and to the making of Italy as an experiment in constitutional choice, it becomes easier to appreciate the problems confronting people in the design of their system of government.

It is entirely possible for fallible human beings to formulate explanations and to use those explanations for undertaking experiments that do not work in anticipated ways. Witness the attempts of French and Russian revolutionists to create new societies and new social orders, The repeated application of a fallacious conception of organization in France led Tocqueville to the conclusion that "in France there is only one thing that we cannot make: a free government; and only one that 
we cannot destroy: centralization. ${ }^{60}$ Experience reveals that a fallacious conception or false principles of organization led Italian "revolutionists" to ignore or try to suppress the nature of the country and the political consciousness of its people. Flaws in its original creation made Italy, in some important respects, highly unstable. ${ }^{61}$ It is in this'sense that Luigi Einaudi, in the aftermath of Fascism, recalled that the fathers of unification "believed that they were establishing liberty and democracy when they were forging the instruments of 62 dictatorship."

Yet, the flaws in design that served to create radical disjunctions between public actions and rhetoric about public purposes and goals also served to foster among Italians a spirit of independence

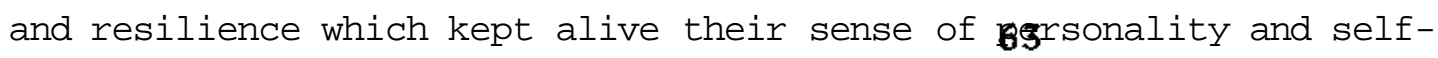
respect. As research on Mussolini and the $\overline{\text { Jews }}$ demonstrates, most Italians remained their essential humaneness even under the worst of 64

regimes; few, in fact, "thought they were free." The critical problem since Italian unification has been how to reflect and incorporate fully the humaneness of people in the organization and conduct of government - in essence, the problem of constitutional choice itself. Many modern analysts have often attributed remarkable intuitions to Cattaneo for his capacity to anticipate patterns of development which 65 occurred long after his works were published. The work by James M. Buchanan on the Italian political economy tradition suggests an alternative explanation: Cattaneo used a mode of reasoning or theory of institutional analysis and design which enabled him to reach important conclusions about the direction that the course of Italian political development would take. Should the day ever come when people living on 
the Italian peninsula and islands have the opportunity, in the words of Alexander Hamilton, ${ }^{66}$ to go back to "first principles, " either alone or as part of a European community, Cattaneo's federalism as the theoryof-democracy-in-action may well serve as a "grand design"-' for a less unperfect experiment in constitutional choice. 
NOTES

Filippo Sabetti is associate professor of political science at McGill University, Montréal, Quẹbèc.

* Research supported by the Canada Council/Conseil des Arts du Canada, the Workshop in Political Theory and Policy Analysis at Indiana University, Bloomington, and the Faculty of Graduate Studies and Research of McGill University as well as the intellectual exchange which I have shared with colleagues in the Workshop on Covenant and Politics of the Center for the Study of Federalism, Temple University, Philadelphia, have contributed many essential ingredients to this article.

${ }^{1}$ Charles Tilly, ed., The Formation of National States in Western Europe (Princeton: Princeton University Press, 1975).

${ }^{2}$ Ibid., p. 37

${ }^{3}$ Ibid.

See, e.g., Roger Benjamin, The Limits of Politics: Collective Goods and Political Change in Post-Industrial Society (Chicago: The University of Chicago Press, 1980); James M. Buchanan, Freedom in Constitutional. Contract: Perspectives of a Political Economist (College Station: Texas A. \& M. University Press, 1977); D.T. Campbell, "Reforms as Experiments," 
American Psychologist 24 (April 1969), pp. 409-429; Elinor Ostrom, "On"Righteousness, Evidence and Reform: The Police Story," Urban Affairs Quarterly 10 (June 1975), 464-486; Vincent Ostrom, "Artisanship and Artifact," Public Administration Review 40 (July/August 1980); and Vincent. Ostrom and Frances Pennell Bish, eds., Comparing Urban Service Delivery Systems: Structure and Performance, vol. 12, Urban Affairs. Ȧnnual Reviews (Beverly Hills: Sage, 1977).

${ }^{5}$ See, e.g., James M. Buchanan, "La scienza delle finanze: The Italian Tradition in Fiscal Theory" in his Fiscal Theory \& Political Economy (Chapel Hill: The University of North Carolina Press, 1960), pp. 24-74, and "Public Finance and Public Choice," National Tax Journal, XXVIII (December 1975), pp. 383-394; the contributions that have appeared in Richard A. Musgrave and Alan T. Peacock, eds. Classics in the Theory of Public Finance (New York: St. Martin's Press, 1964); and F. Sabetti, "Theory of Public Policy: European Contributions" in Stuart S. Nagel, ed., Policy Studies in America and Elsewhere (Lexington, Mass.: Heath \& Co., Lexington Books, 1975), pp. 41-49.

6 Denys Hay, The Italian Renaissance in Its Historical Background (Cambridge: àt. the University Press, 1961), pp. 26-27; see also Clara M. Lovett, Giuseppe Ferreri and the Italian Revolution (Chapel Hill: The University of North Carolina Press, 1979), pp..102-104.

${ }^{7}$ Giovanni Sartori, "From the Sociology of Politics to Political Sociology," in S.M. Lipsett, ed., Politics and the Social Sciences (New York: Oxford University Press, 1969), pp. 65-100. ${ }^{8}$ See, e.g., the collection of interpretations in Charles F. Delzell, 
ed., The Unification of Italy, 1859-1861. Cavour, Mazzini, or Garibaldi? (New York: Holt, Rinehart and Hinston, 1965); Umberto Marce11i, Interpretazioni del Risorginento (3rd ed., Bologna: Patron, 1970); and Denis Mack Smith, Victor Enmanue1, Cavour and the Risorgimento (London: Oxford University. Press, 1971).

${ }^{9}$ Alberto Asor Rosa, Storia d'Italia, vol. IV (Turin: Einaudi, 1975), pp. 840-841; Denis Mack Smith, "Regionalismo," in E.R. Tannenbaum and E.P. Noether, eds., Modern Italy. A Topical History since 1861 (New York: New York University Press, 1974), chapter 6, and D. Mack Snith, ed., The Making of Italy, 1796-1870 (New York: Walker, 1968), pp. 70-73. But cf., Luigi Salvatorelli who in his The Risorgimento: Thought and Action (New York: Harper and Row, 1970), p. 7 avers that "(c)enturies before the formation of a unified Italian state, there had existed an Italian people."

10 Antonio Gramsci, I1 Risorgimento, quoted in Alexander Gerschenkron, "Rosario Romeo and the Original Accumulation of Capital" in his collection of essays on Economic Backwardness in Historical Perspective (Cambridge, Mass: The Belknap Press of Harvard University Press, 1962), p. 92.

${ }^{11}$ G. F.-H. and J. Berkeley, Italy in the Making, vol. II (Cambridge at the University Press, 1936), p. xxii.

12E.g., Nino Cortese, La prima rivoluzione separatista siciliana 1820-1821 (Naples: Libreria Scientifica Editrice, 1956).

13 Extracts of his essay in Denis Mack Smith, ed., The Making of Italy 1796-1870, pp. 11-14.

${ }^{14}$ Ibid, p. 14. 
${ }^{15}$ See, e.g., Franco Della Peruta, I democratici e 1a rivoluzione italiana (Milan: Feltrinelli, 1958), p. 14.

${ }^{16}$ Bolton King, A History of Italian Unity vol. 1 (London: James Nisbet, 1899), p. 132 .

${ }^{17}$ V. Gioberti, quoted in D. Mack Smith, ed., The Making of Italy, 1796-1870, p. 84 .

${ }^{18}$ Ibid., p. 82.

${ }^{19}$ Ibid., p. 83 .

20 Bolton King, op. cit., vol. 1, p. 155.

${ }^{21}$ Selected passages of Balbo's work may be found in D. Mack Snith, ed., The Making of Italy, 1796-1870, pp. 84-92.

22 Bolton King, op. cit., vol. I, p. 157.

${ }^{23}$ See, e.g., Carlo Cattaneo, Scritti politici. 4 vols. (Edited by Mario Boneschi. Florence: Le Monnier, 1964-65); Ettore A. Albertoni, "L'Autonomismo regionale lombardo da C. Cattaneo alla Costituzione repubblicana," Archivio Storico Siciliano III (1977), pp. 3-23; Norberto Bobbio, Una filosofia militante. Studi su Carlo Cattaneo (Turin:

Einaudi, 1971); Clara M. Lovett, Carlo Cattaneo and the Politics of the Risorgimento 1820-1860 (The Hague: Nijhoff, 1972); and Antonio Monti, L'Idea Federalistica ne1 Risorgimento Italiano (Bari: Laterza, 1922).

${ }^{24}$ Vincent Ostrom, The Political Theory of a Compound Republic. A Reconstruction of the Logical Foundations of American Democracy as Presented in 'The Federalist' (Blacksburg: Virginia Polytechnic Institute and University, Center for Study of Public Choice, 1971). 
${ }^{25}$ See, e.g., the discussion of Cattaneo's theory of democracy by Delia Castelnuovo Frigessi in her "Introduzione" to Cattaneo's writings, Industria e Scienza Nuova. Scritti 1833-1839 (no. 124. Turin: Einaudi, 1972). pp. vii-1xxx. Though much has been written in Italian on Cattaneo, his work has yet to receive the attention it deserves by students of political theory and policy analysis. Cattaneo's conception of federalism as "the theory of democracy in action" has all the characteristics of what Daniel J. Elazar and other analysts refer to as "Federalism as Grand Design" Publius 9 (Fall 1979).

${ }^{26}$ Kent R. Greenfield, Economics and Liberalism in the Risorgimento. A Study of Nationalism in Lombardy, 1814-1848 (rev. ed. Baltimore: The Johns Hopkins University Press, 1965), 286-287. See also the recent work by Ettore A. Albertoni, La vita degli stati e l'incivilimento dei popoli ne1 pensiero politico di Gian Domenico Romagnosi (Milano: Dott. A Giuffré Editore, 1979).

${ }^{27}$ See, e.g., Rosario Romeo, I1 Risorgimento in Sicilia (rev. ed., Bari: Laterza, 1973), pp, 317-345.

${ }^{28}$ Raymond Grew, A Sterner Plan for Italian Unity. The Italian Nationa1 Society in the Risorgimento (Princeton: Princeton University. Press, 1963), p. 5.

29 Ibid.

${ }^{30}$ Bolton King, op. cit., vol. 1, pp. 359-360.

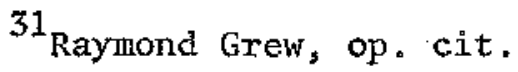

${ }^{32}$ Bolton King, op. cit., vol. II, p. 22. 
A.J.P. Taylor, The Italian Problem in European Diplomacy 18471849 (Manchester: Manchester University Press, 1934), esp. pp. 10-12 and 236-239.

${ }^{34}$ Denis Mack Smith, ed., The Making of Italy 1796-1870; p. 234. 35

See, e.g., the analysis by W.K. Hancock, Ricasoli. and the .. Risorgimento in Tuscany (new ed., New York: Howard Fertig; 1969; originally published in 1926).

The use of the term "decentralization" here follows that suggested by Daniel Elazar in his "Community Self-Government and the Crisis of American Politics," $\overline{\text { Ethics, }} 81$ (January 1971), pp. 91-106. Elazar reminds, us, in part, that decentralization implies an allocation of authority from the center by a superior authority to a subordinate set of authorities. Federalism implies noncentralization of authority. See also Vincent Ostrom "The Contemporary Debate over Centralization and De-

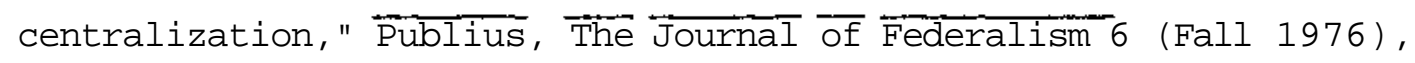
pp. 21-32.

37

Francesco Brancato, La Sicilia nel primo ventennio del Regno d'Italia (Bologna: Cesare Zuffi Editore, 1956), pp. 69-153, and "Carlo Cattaneo e 1'Opposizione Democratica in Sicilia'e a Napoli nel 1860," Nuovi Quaderni $\overline{\text { del Meridione I }}$ (1963), pp. i-26; Massimo Ganci, $\overline{\text { L'Italia }}$ antimoderata..$\overline{\text { Radicali, }}$ repubblicani, socialisti, autonomisti dall'Unita - - ...

a oggi (Parma: Guanda, 1968); Francesco Perez, La centralizzazione

e la liberta. (Palermo: Stabilimento Tipografico di Francesco Lao, 1862); and Rosario Romeo, op. cit., pp. 256-388.

Ju his discussion of the Italian contribution to Fiscal Theory 
and Political Economy (Chapel Hill, N.C.: The University of North Carolina Press, 1960), James Buchanan makes the following observation about Francesco Ferrara: "Of all the Italians, Pareto included, Ferrara must assume first rank, and in his work may be found germs of later developments, not only in fiscal theory, but in all of economic theory as well"

F. Ferrara's memorandum "Brevi note sulla Sicilia," written on about July 8, 1860, was circulated anonymously in Sicily during the summer of 1860 . It has been published in Cavour's papers, $\bar{C}$. Cavour, Carteggi, La Liberazione del Mezzogiorno e la Formazione del Regno d'Italia, vol. I (Bologna: Zanichelli, 1949), pp. 296-305. All the subseguent references to Ferrara's "Brevi Note" are from this source. Ibid., pp. 296-297.

40 ,

${ }^{41}$ Ibid., p. 297.

42 Ibid., p. 298.

${ }^{43}$ Ibid., p. 299.

${ }^{44}$ Ibid.

${ }^{45}$ Ibid., pp. 300-301.

${ }^{46}$ Ibid., p. 302 .

${ }^{47}$ Ibid., p. 303 .

${ }^{48}$ Ibid., p. 304; this and the subsequent quotation have been rearranged.

49 Ibid. 
Ibid.

$\mathbf{5 1}$ Cavour to Michele Amari, a friend of Ferrara, ibid., p. 305.

52

Denis Mack Smith, (Cambridge: at the University Press, 1954), pp. 388-389, 402-403.

$\mathbf{5 3}$ Robert C. Fried, The Italian Prefects. A Study in Administrative Politics (New Haven: Yale University Press, 1963), pp. 72-119; Claudio Pavone, Amministrazione centrale e amministrazione periferica da Rattazzi a Ricasoli (1859-1866) (Milano: Giuffrè, 1964); and Ernesto Ragioneri, "Politica e amministrazione nello Stato unitario," in his Politica e_ anministrazione nella storia dell'Italia unita (Bari: Laterza, 1967); Antonio Troccoli, II Problema della "Regione" in Italia (Firenze: Noccioli Editore, 1964).

54

Robert C. Fried, op. cit., p. 116.

${ }^{55}$ Ibid., p. 118 .

$\mathbf{5 6}$ For an elaboration of this point see my "The structure and Performance of Urban Service Systems in Italy," in Vincent Ostrom and Frances Pennell Bish, eds., op. cit.

57

Giuseppe Di Palma, Political Syncretism in Italy: Historical Coalition Strategies and the Present Crisis (Berkeley: University of California, Institute of International Studies, 1978).

58 Antonio Gramsci, "The Problem of Political Leadership in the Formation and Development of the Nation and the Modern State in Italy," in Quintin Hoare and Geoffrey Nowell Smith, eds., Selections From the Prison Notebooks of Antonio Gramsci (New York: International Publishers, 1978), p. 90 . 
${ }^{59}$ See, e.g., Giuseppe Di Palma, "Eurocommunism?" Comparative Politics 9 (April 1977), pp. 357-375, and Norberto Bobbio, "Is There a Marxist Theory of the State?" Telos 35 (Spring 1978), pp. 5-30.

60 Alexis de Tocquevilie, Recollections (ed. by J.P. Mayer and A.P. Kerr. Garden City, New York: Doubleday, Anchor Books, 1971), p. xviii.

${ }^{61}$ Denis Mack Smith, Cavour and Garibaldi 1860 , p. 6, and "Regionalism," in op. cit.

62 Luigi Einaudi, "Via al prefetto!" in his Il Buongoverno: Saggi di Economia e Politica, 1897-1954 (ed. by E. Rossi. Bari: Laterza, 1954), p. 52; see also Denis Mack Smith, "A prehistory of Fascism," in A. William Salomone, eds, Italy From the Risorgimento to Fascism (Garden City, N.Y.: Doubleday, Garden Books, 1970), pp. 103-123.

63 Meir Michaelis, Mussolini and the Jews: German-Italjan Relations and the Jewish Question in Italy 1922-1945 (New York: Oxford University Press, 1979).

${ }^{64}$ Mi1ton Mayer, They Thought They Were Free. The Germans 1933-45 (Chicago: The University of Chicago Press, 1955).

${ }^{65}$ James M. Buchanan, op. cit.

${ }^{66}$ Quoted in Vincent Ostrom, Leviathan and Democracy: An Introduction to the Theory of Political Choice (Bloomington, Indiana: Indiana University, Workshop in Political Theory and Policy Analysis, Working Paper 1980), p. 1-5.

${ }^{67}$ Daniel J. Elazar, "Federalism as Grand Design," in op. cit., pp.1-8. 